\title{
Методичний підхід для формулювання вимог до системи відновлення озброєння та військової техніки
}

\author{
Володимир Коцюруба ${ }^{1}$ А; Вадим Сівак 2 в; Олег Угринович 3 А \\ А Національний університет оборони України імені Івана Черняховського, м. Київ, Україна \\ в Національна академія Державної прикордонної служби України імені Богдана Хмельницького, м. Хмельницький, Україна
}

Received: August 15, 2021 | Revised: August 24, 2021 | Accepted: August 31, 2021

DOI: $10.33445 / s d s .2021 .11 .4 .14$

\begin{abstract}
Анотація
Під час планування загальновійськового бою (операції) органами управління визначаються можливості системи відновлення озброєння та військової техніки, яка є складовою загальної системи забезпечення військ (сил). Саме від ефективності функціонування системи відновлення озброєння та військової техніки залежить рівень укомплектованості військових частин (підрозділів) справними зразками озброєння та військової техніки, що визначає рівень їх боєздатності.

Досвід виконання завдань військовими частинами (підрозділами) на території Донецької та Луганської областей вказує на те, що система відновлення озброєння та військової техніки не в повній мірі забезпечує виконання завдань щодо своєчасного відновлення пошкоджених зразків озброєння та військової техніки.

Основні завдання системи відновлення озброєння та військової техніки в ході бойових дій (операції), полягають у технічній розвідці, евакуації, ремонті та технічному обслуговуванні ОВТ. Відповідно на ієрархічному рівні основні завдання для тактичної ланки полягають у підтриманні бойового потенціалу військових частин (підрозділів) шляхом відновлення усього ремонтного фонду за рахунок проведення поточних ремонтів, а оперативному у періодичному поповненні військових частин (підрозділів) озброєнням та військовою технікою за рахунок проведення середніх ремонтів.

Критерієм досягнення системою поставленої мети визначено задану кількість справного озброєння та військової техніки в строю на кінець операції, а критерієм виконання завдань за рівнями ієрархії визначено ефективність відновлення озброєння та військової техніки. У статті визначено, що якщо система відновлення тактичного рівня не буде охоплювати увесь ремонтний фонд то він буде передаватись в оперативний рівень, що призведе до зниження ефективності системи відновлення оперативної ланки.
\end{abstract}

Ключові слова: ефективність, відновлення озброєння та військової техніки, ремонтний фонд.

\section{Постановка проблеми}

Досвід війн та збройних конфліктів сучасності, ведення операції об'єднаних сил на території Донецької та Луганської областей свідчить, що успіх у виконанні завдань військами (силами) під час ведення бойових дій (операції) значною мірою залежить від функціонування системи відновлення озброєння та військової техніки (ОВТ), яка $є$ складовою системи логістичного забезпечення. На даний час одним із основних проблемних аспектів функціонування системи відновлення ОВТ за визначених умов $\epsilon$ значне перевищення темпів розвитку та застосування засобів

\footnotetext{
${ }^{1}$ Corresponding author: доктор технічних наук, професор, професор кафедри, e-mail: kotcuru@ukr.net, ORCID: 0000-0001-6565-9576 2 доктор технічних наук, професор, провідний науковий співробітник науково-дослідної лабораторії, e-mail: vadimsivak@gmail.com, ORCID: 0000-0002-8262-4831

${ }^{3}$ кандидат військових наук, професор кафедри, e-mail: olegenya999@gmail.com, ORCID: 0000-0001-6644-7620
} 
ураження у порівнянні із засобами захисту. Низька ефективність засобів захисту зразків ОВТ, різнотипність базових шасі, велика номенклатура запасних частин, недосконалість системи забезпечення, а саме підсистеми технічної розвідки, евакуації, ремонту пошкоджених зразків ОВТ, забезпечення матеріальними засобами, структури рухомих та стаціонарних ремонтновідновлювальних органів призводить до несвоєчасного повернення зразків ОВТ у військові частини (підрозділи), які ведуть бойові дії.

3 переходом Збройних Сил (3С) України на систему логістичного забезпечення змінюються завдання, які вирішувались за допомогою засобів, які призначенні для відновлення пошкоджених зразків ОВТ. В свою чергу, це вимагає створення вимог до перспективної системи відновлення ОВТ військових частин, модернізації і розробки новітніх засобів та комплексів, які б відповідали умовам щодо ремонту пошкоджених зразків ОВТ під час ведення бойових дій та одночасній потребі щодо виконання завдань 3 ремонту ОВТ в стаціонарних умовах.

Тому, питання, які пов'язані 3 удосконаленням методичних підходів щодо функціонування системи відновлення ОВТ $\epsilon$ досить актуальними та потребують дослідження.

\section{Аналіз останніх досліджень та публікацій}

Дослідженню питань організації та проведення відновлення ОВТ вченими приділяється досить багато уваги, в зв'язку з веденням восьмого року війни на Сході нашої держави. Робота [1] присвячена аналізу військових технічних систем 3 метою виявлення проблемних питань та пошуку шляхів для їх вирішення. Запропоновано підхід щодо підвищення ефективності функціонування системи логістики. В роботі [2] розглянуто методичний апарат оцінювання оперативно-тактичних вимог до системи відновлення та визначення їх відповідності вимогам більш вищого рівня ієрархії із застосуванням теорії складних систем. В роботах [3-5] досліджуються питання окремих складових системи відновлення ОВТ, але не розглядаються питання на скільки система відновлення виконує поставлені завдання. В роботі [6] розглядається вплив зовнішніх і внутрішніх чинників на організацію відновлення ОВТ, при цьому не враховуються тенденції змін у формах і способах застосування військ (сил). В роботі [7-8] описано модель функціонування сил і засобів технічного забезпечення та визначено величину зниження збитків за рахунок функціонування системи відновлення, але невизначено чи система відновлення справляється 3 функціональним призначенням.

вимоги до структури та параметри перспективної організаційно-технічної системи відновлення ОВТ.

Ці обмеження й обумовили потребу у вирішенні наукового завдання сутність якого полягає в формулювання вимог до системи відновлення.

Мета статті полягає у розробленні вимог до системи відновлення ОВТ у відповідності до тактики дій військ (сил) і врахування форм і способів їх застосування. 


\section{Виклад основного матеріалу}

Відповідно до системної методології, вимоги до системи відновлення ОВТ розробляється в кілька етапів, головними 3 яких $\in$ [9]:

виявлення проблеми, тобто встановлення факту недостатньої відповідності системи відновлення ОВТ їі цільовому призначенню;

формулювання проблеми, тобто визначення за якими критеріями і в яких ситуаціях система не справляється із своїм функціональним призначенням;

аналіз сутності проблеми, тобто виявлення причин недостатньо ефективного функціонування системи. Цей етап $€$ одним 3 найскладніших, відповідальних і трудомістких. Саме він дозволяє визначити шляхи вирішення проблеми, які будуть вказані у визначених вимогах.

Порядок формулювання вимоги до системи відновлення ОВТ можна розподілити на декілька груп, перед визначенням яких вказати загальну мету та ідею вдосконалення системи відновлення ОВТ.

У першій групі повинні бути сформульовані призначення системи відновлення ОВТ. Визначено її місце в ієрархії взаємодіючих з нею систем і зв'язок з ними: по вертикалі - 3 вищестоящими i, по горизонталі - 3 системами того ж рівня ієрархії. Необхідно виявити просторово-часові обмеження умов функціонування системи відновлення ОВТ.

Друга група повинна містити уточнену мету системи відновлення ОВТ, критерії оцінки ії функціональної ефективності, найважливіші завдання, які забезпечують досягнення головної мети.

У третій групі вказуються конкретні напрямки вдосконалення системи відновлення ОВТ, тобто шляхи вирішення проблеми, яка виникла. Ця група вимог найбільша за обсягом та визначає ефективність удосконаленої системи відновлення ОВТ.

У четверту групу можуть бути включені обмеження із виділення матеріальнотехнічних засобів (МТ3), а також рекомендації
3 оцінювання економічної ефективності запланованих заходів.

Система відновлення ОВТ існує з часів прийняття на озброєння бойових броньованих машин, автомобільної техніки, засобів вогневого ураження, тощо і пройшла неодноразові зміни щодо удосконалення, однак цей процес буде відбуватись постійно в залежності від зміни форм та способів застосування військ (сил), які також будуть залежати від розвитку та прийняття на озброєння сучасних зразків ОВТ. Оскільки $з$ точки зору системного підходу відновлення ОВТ входить в систему забезпечення військ (сил), то заходи з відновлення ОВТ з одного боку є обмеженням, а з іншого стимулом для удосконалення заходів щодо розвитку системи, яка обслуговує війська (сили). До їх числа відносяться зміни в поглядах на застосування механізованих (танкових), частин і підрозділів у різних видах бою (операції), адаптація їх до різних театрів бойових дій. Такі зовнішні чинники, як характеристики безвідмовності, уразливості, ремонтопридатності зразків ОВТ, відновлюваності ОВТ, технологія виробництва і ремонту ОВТ також впливають на вдосконалення системи відновлення у певних напрямках [10].

Аналіз процесу функціонування системи відновлення ОВТ [11] вказує на доцільність обмеження просторово-часовими показниками бою (операції). Дані обмеження дадуть можливість виключити з розгляду стаціонарні ремонтні ланки, які забезпечують поповнення військ ОВТ, як правило, в період між боями. У заданих межах функціонування системи нам відомі мета системи, завдання основної, допоміжної і підсистеми забезпечення, а також структурноорганізаційні рівнів. Мета системи конкретизується в залежності від заданого бойового потенціалу військ за наявністю в строю ОВТ протягом планованого періоду бою (операції).

Завдання підсистем: основної - технічне обслуговування і ремонт ОВТ, які вийшли 3 
ладу; допоміжної - розвідка ремонтного фонду (РемФ) і ОВТ, які підлягають евакуації, евакуація та транспортування; забезпечення - усі види МТЗ.

Завдання за рівнями ієрархії: тактичного щодобове підтримання бойового потенціалу підрозділів і частин шляхом відновлення щодоби усього обсягу РемФ ОВТ поточного ремонту; оперативного - періодичне в ході операції поповнення військ ОВТ за рахунок проведення максимальної кількості середніх ремонтів ОВТ. Ці завдання забезпечують відновлення бойового потенціалу, як за обсягом, так і за темпом. Критерієм досягнення системою поставленої мети прийнято вважати задану кількість справного ОВТ в строю на кінець операції. Критерієм виконання завдань за рівнями вважають ефективність відновлення ОВТ $\left(\mathrm{N}_{\text {вдд }}\right)$, тобто відношення кількості реально відновлених зразків ОВТ $\mathrm{Z}$ ланками даного рівня до загального обсягу РемФ $\mathrm{G}$, який повинен бути ними відновлено [12]

$$
N_{\text {від }}=\frac{Z}{\mathrm{G}}
$$

Позначимо вид і ступінь ремонту індексом, який може приймати значення від 1 до 6. При цьому: $-k=1$ поточний ремонт до 10 людгод; $k=2$ - поточний ремонт до 20 люд-год, тощо.

Позначимо індексом $j$ ланки структури військ і ланки системи відновлення ОВТ, які їм належать. Він може приймати значення від 1 до 5. При цьому: $j=1$ - батальйон; $j=2-$ бригада; $j=3$ - оперативно-тактичне угрупування військ, $j=4$ - оперативне угрупування військ, $j=4$ - оперативностратегічне угрупування військ. Тоді можна записати:

$$
\begin{gathered}
N_{\mathrm{Bi}} j=(1 \ldots 3)=\frac{Z_{j=(1 \ldots 3)}}{\mathrm{G}_{\mathrm{j}=(1 \ldots 3)}} \\
N_{\mathrm{Bi} j j=(4 \ldots 5)}=\frac{Z_{j=(4,5)}+\left(1-\frac{\bar{\tau}_{j=3}}{\tau_{j=4}}\right)\left(1-N_{\mathrm{Bi} j j=(1 \ldots 3)}\right) G_{k=(1 \ldots 3)}}{\mathrm{G}_{\mathrm{k}=(4,6)}+\left(1-N_{\mathrm{Bi} j j=(1 \ldots 3)}\right) G_{k=(1 \ldots 3)}}
\end{gathered}
$$

У рівнянні (3) враховується, що частина РемФ, що не охоплена на тактичному рівні $G_{k=(1 . .3)}\left(1-N_{\text {відj=(1-3) }}\right)$, передається на оперативний i, згідно з принципом пріоритету, відновлюється в ньому в першу чергу. При цьому за рахунок залучення ремонтних бригад на відновлення додаткового РемФ не буде охоплена ремонтом певна частина РемФ оперативного рівня, тобто зразки ОВТ, які потребують середнього ремонту. Ця частина враховується коефіцієнтом $C$

$$
C=\left(1-\frac{\bar{\tau}_{j=3}}{\bar{\tau}_{j=4}}\right)
$$

де $\bar{\tau}_{\mathrm{j}=3}-$ середня трудомісткість ремонту в суміжних ланках тактичного рівня $j=3-$ рвб бригади; $\bar{\tau}_{\mathbf{j}=4}$ - середня трудомісткість ремонту в суміжних ланках оперативного рівня: $j=4-$ орвп оперативного командування (оперативно-тактичного угрупування військ).

Практично В оперативний рівень в переважній більшості випадків буде передаватися РемФ тільки з вищої ланки тактичного рівня (бригад), а РемФ капітального ремонту в ході операції оперативно-тактичного угрупування військ відновлюватися не буде. Тоді вираз (4) набуде вигляду

$$
N_{\mathrm{Bi} j}=(4,5)=\frac{Z_{j=(4,5)}+\mathrm{C}\left(1-N_{\mathrm{Bi}} j=3\right) G_{k=3}}{\mathrm{G}_{\mathrm{k}=(4,6)}+\left(1-N_{\mathrm{Bi} j} j=3\right) G_{k=3}}
$$

Функціональна залежність $y=\frac{a+C x}{b+x}$ при $a<b$ i C $<1$, до якої приводиться (5), володіє наступними властивостями: 
При $\mathrm{C}=\frac{a}{b} \quad y=\frac{a}{b}=$ const; при $\mathrm{C}>\frac{a}{b}$ із збільшенням аргументу функція зростає, а при $\mathrm{C}<\frac{a}{b}-$ убуває

Відмітимо, що

$$
\frac{a}{b}=\frac{Z_{j=(4,5)}}{G_{k=(4,6)}}
$$

відношення величин $a$ і $b \in$ середня надійність відновлення ОВТ оперативного рівня в умовах відсутності передачі РемФ 3 тактичного рівня.

3 огляду на вираз (4), (6), а також те, що вираз (5) $з$ відповідною індексацією справедливий для будь-якої $j$-ї ланки при передачі в неї РемФ з батальйонної ланки $(j-$ 1), можна сформулювати наступний загальний висновок:

при передачі РемФ з нижчої ланки до вищої ефективність відновлення ОВТ в оперативній ланці зменшується, якщо різниця між одиницею i відношенням середніх трудовитрат цих ланок менше вихідної ефективності відновлення ОВТ, тобто $\left(1-\frac{\bar{\tau}_{\text {н }}}{\bar{\tau}_{\text {в }}}\right)<\bar{N}_{\text {відвих }}$ В іншому випадку ефективність відновлення вищої ланки залишиться постійною при $1-\frac{\bar{\tau}_{\text {H }}}{\bar{\tau}_{\text {в }}}=\bar{N}_{\text {відвих }}$ або збільшується при $\left(1-\frac{\bar{\tau}_{\text {н }}}{\bar{\tau}_{\mathrm{B}}}\right)>\bar{N}_{\text {відвих. }}$

Інакше кажучи, при невеликій різниці між середніми трудомісткостями ремонту у вищій і нижчій ланках імовірність зменшення ефективності відновлення у вищій ланці при передачі до неї РемФ з нижчої зростає. Отже, при створенні системи відновлення ОВТ доцільно ставити їй трудомісткості ремонту, які істотно відрізняються від середніх при максимально можливій ефективності відновлення кожної ланки.

Для кожного рівня ефективність відновлення ОВТ може бути визначена не тільки за всю операцію, а й за кожен день. Особливо доцільним $€$ таке визначення для аналізу функціонування тактичного рівня системи відновлення ОВТ.

Позначимо індексом $d$ поточні дні операції. Тоді $d=0$-початок операції, $d=D$ - кінець операції.

Рівень бойового потенціалу, за наявністю техніки в строю на кінець операції, так само як і тривалість операції $D$, задається. Необхідний

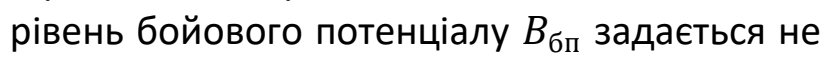
кількістю, а часткою справного ОВТ на кінець операції в процентах від кількості на початок операції

$$
B_{\text {бп }}=\frac{A_{d=D}}{A_{d=0}} 100 \%
$$

3 досвіду бойових дій, військових навчань і науково-дослідних робіт для різних сучасних умов бойових дій відомі очікувані сумарні середньодобові втрати ОВТ за операцію в

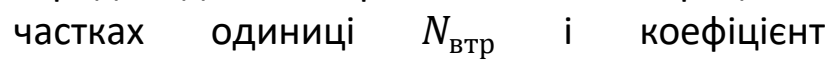

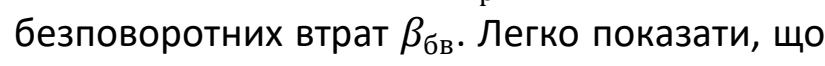
кількість зразків ОВТ в строю на кожен день операції з урахуванням їі відновлення буде визначатися виразом

$$
A_{d}=A_{d=0}\left[\left(1-N_{\text {вmp }}\right)+N_{\text {вid }} N_{\text {вmp }}\left(1-\beta_{\text {бв }}-\beta_{\kappa p}\right)\right]
$$

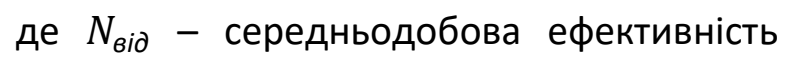
відновлення ОВТ усієї системи;

$\beta_{к р}$ - імовірність наявності в загальному обсязі втрат РемФ капітального ремонту, який не відновлюється в ході операції оперативнотактичного угрупування військ.

Множник $\left[\left(1-N_{\text {втр }}\right)+N_{\text {від }} N_{\text {втр }}\left(1-\beta_{6 в}-\right.\right.$ $\left.\left.\beta_{\kappa p}\right)\right]$ визначає середнє зниження бойового потенціалу по наявності ОВТ в строю. Позначимо його через $\alpha$

$$
\alpha=\left(1-N_{\text {вmp }}\right)+N_{\text {вid }} N_{\text {вmp }}\left(1-\beta_{6 в}-\beta_{\kappa p}\right)
$$

Сума представляє собою частку справного ОВТ після кожного тижня бою, що минув. Сума $\epsilon$ часткою втрат, що підлягають 
відновленню в ході операції. Формула (8) набуде вигляду

$$
A_{d}=A_{d=0} \alpha
$$

3 рівнянь (7) - (8) можна отримати необхідне значення ефективності відновлення ОВТ, за рахунок збереження укомплектованості військ (сил) ОВТ на заданому рівні протягом операції,

$$
\bar{N}_{B}=\frac{D \sqrt{\frac{B_{6 n}}{100}-\left(1-N_{\text {smp }}\right)}}{N_{\text {вmp }}\left(1-\beta_{6 в}-\beta_{\kappa p}\right)}
$$

Шляхом нескладних перетворень, які враховують імовірний розподіл РемФ по структурно-організаційним рівням, можна отримати необхідні значення ефективності відновлення (для рівнів системи і для окремих її ланок. Ці значення будуть служити показниками якості функціонування ланок, рівнів і всієї системи відновлення ОВТ в цілому. Значення ж, отримані за формулами (2) і (3), визначать ступінь наближення реально діючої системи відновлення ОВТ до заданих показників. Вимоги на вдосконалення системи відновлення ОВТ повинні містити необхідні значення ефективності відновлення ОВТ усієї системи і кожного рівня ієрархії.

Необхідні значення ефективності відновлення ОВТ визначаються на базі усереднених і імовірнісних характеристик втрат ОВТ, розподілу РемФ по трудомісткості, оперативно-тактичних чинників та інших

\section{Висновки}

Таким чином, у вимогах на вдосконалення системи відновлення ОВТ слід задавати і показники функціональної ефективності.

Вимоги, які встановлюють певні критерії досягнення поставленої мети, повинні вказувати і шляхи вдосконалення системи відновлення ОВТ. Удосконалення системи відновлення ОВТ, може здійснюватися за трьома напрямками: поліпшення процесу їі функціонування, створення більш показників. У конкретних реалізаціях процесів ці показники будуть приймати фіксовані значення. Тому дійсна ефективність відновлення ОВТ може значно відрізнятися від заданої. Розбіжність може посилюватися зміною виробничих можливостей ланок системи відновлення ОВТ за рахунок втрат особового складу i рухомих засобів відновлення ОВТ [13], перебоїв в постачанні запасними частинами, матеріалами, оборотними агрегатами, а також різкими відхиленнями від середньостатистичних значень обсягу і характеру ремонтних робіт. В системі повинні бути передбачені певні можливості 3 компенсації таких розбіжностей. Тобто система відновлення ОВТ повинна адаптуватись щодо маневру силами і засобами, чітким виконання допоміжних завдань i завдань із забезпечення чим визначається ії функціональна ефективність $\left(E_{\phi}\right)$. Вона може бути виражена як імовірність $P$ того, що система відновлення в будь-яких ситуаціях із заданим ступенем наближення виконає поставлене завдання

$$
E_{\phi}=P\left[N_{\text {н.н.в. }}-N_{p}\right] \leq \Delta
$$

де $N_{\text {н.н.в. }}$ - необхідна ефективність відновлення;

$N_{p}$ - ефективність відновлення в конкретній реалізації;

$\Delta$ - задане значення відхилення від необхідної ефективності відновлення.

раціональної структури і укомплектування системи новими, більш досконалими засобами технологічного оснащення [6].

Також удосконалити систему відновлення можна за рахунок вдосконалення системи управління. Однак реалізація цього напрямку буде пов'язана з удосконаленням по одному з перерахованих трьох напрямків реалізація яких призведе до певних змін в системі управління [14]. 
Найбільш корінні перетворення зазнає система відновлення ОВТ при зміні їі процесу. Тобто, процес через програму функціонування тісно пов'язаний з усіма складовими системи відновлення ОВТ. Найбільш стійкими складовими є принципи функціонування системи. Як уже зазначалося, стійкість цих принципів обумовлена в першу чергу вдалою розробкою, точністю, перспективністю тих ідей, які були закладені при створенні системи відновлення ОВТ і випробуваннях її в ході ведення бойових дій. Крім того, принципи функціонування, будучи з'єднувальною ланкою системи відновлення ОВТ з вищестоящими системами, можуть бути змінені лише як наслідок істотних змін у вищих системах.

Зміна принципів неодмінно потягне за собою зміну програми функціонування системи відновлення ОВТ. Однак зміна програми функціонування системи відновлення ОВТ може виявитися і вихідним заходом, проведеним безпосередньо 3 метою удосконалення виробничого процесу. Так, наприклад, при переході системи з мирних умов у воєнні програма різко змінюється, чим і забезпечується ефективне їі функціонування у воєнний час. Зміна програми може відбуватися також під впливом вдосконалення технології. Стимулом і одночасно обмеженням вдосконалення технології виступають науково-технічні досягнення [15].

Програма функціонування безпосередньо впливає на розподіл функцій за рівнями і ланками структури системи відновлення ОВТ, на організацію зв'язків між ними тобто на систему управління. Вона пов'язана 3 раціональним розподілом функцій між рухомими засобами відновлення. Удосконалення складових структури відбувається за рахунок удосконаленням програми, в той час як підвищення якості рухомих засобів відновлення або збільшення їх кількості викликає необхідність удосконалення програми через більш раціональний розподіл функцій між ними. При цьому, кількість рухомих засобів відновлення ОВТ обмежується економічними можливостями, а якість - головним чином науково-технічними досягненнями [16].

Економічними можливостями визначається і верхня межа кількості ланок (виробничих підрозділів) структури системи відновлення ОВТ. Нижня ж межа цього показника встановлюється вимогами системи, яка обслуговується. Зміна кількості виробничих підрозділів тягне за собою, 3 одного боку, необхідність встановлення нових зв'язків, а з іншого - перерозподіл функцій між ними. Це призводить до удосконалення функцій управління та зміни програми функціонування системи відновлення ОВТ [17].

3 аналізу можливих шляхів вдосконалення системи відновлення ОВТ випливає, що практично будь-який вплив на систему 3 метою підвищити ї̈ функціональну ефективність тягне за собою ті чи інші зміни по всім ії̈ складовим. Цей висновок ще раз підтверджує необхідність підходу до системи відновлення ОВТ, як до єдиного організму. Одночасно цей висновок свідчить про те, що кількісна оцінка результатів впливу на систему відновлення ОВТ являє собою досить складну задачу. Складність ії обумовлена, поперше, взаємозв'язком усіх якісних i кількісних характеристик системи відновлення ОВТ, а по-друге, невизначеністю ситуацій їі функціонування. В одних ситуаціях конкретний захід може викликати суттєве підвищення функціональної ефективності, а в інших - невиконання системою відновлення ОВТ поставлених перед нею завдань.

Остаточний і об'єктивний вибір шляхів і конкретних заходів щодо вдосконалення системи відновлення ОВТ і включення цих заходів у вимоги можливі лише на підставі кількісної оцінки функціональної ефективності системи у великому наборі різних ситуацій ії функціонування. 


\section{Список використаних джерел}

1. Обґрунтування концептуальних та наукових підходів щодо розвитку єдиної системи логістики в Збройних Силах України / [Власов І. О., Воробйов О. М., Наконечний О. В., Середа, Ю. С.]; Збірник наукових праць "Харківського національного університету Повітряних Сил імені Івана Кожедуба - Харків. - 2020. № 2(64). C. 12-18. DOI: 10.30748/zhups.2020.64.02

2. Дачковський В.О. Методика оцінювання ефективності функціонування системи відновлення озброєння та військової техніки / В.О. Дачковський, В.І. Коцюруба // науковий журнал "Сучасні інформаційні технології у сфері безпеки та оборони", НУОУ. - 2020. - № 1(37) С. 5 - 14. DOI:10.33099/2311-7249/2020-37-1-5-14

3. Чуев Ю. В.Исследование операций в военном деле / Чуев Ю. В. М.: Воениздат, 1970. -256 с.

4. Syrotenko, A., Datsenko, I., Kotsiuruba, V., Yalnytskyi, O., Holda, O., Nedilko, O., Dachkovskyi, V. Experimental investigation of impact of injury measures on the protection screens of combat armoured vehicles. Strength of Materials and Theory of Structures. 2020, No. 104, p. 117-135. DOI: 10.32347/2410-2547.2020.104.117-135

5. Коваленко О. А. Оцінювання можливостей ремонтно-відновлюваних органів 3 евакуації пошкоджених зразків озброєння та військової техніки / О. А. Коваленко // Сучасні інформаційні технології у сфері безпеки та оборони. - 2016. - № 1. - С. 5558. URL: http://nbuv.gov.ua/UJRN/sitsbo_2016_1_12

6. Dachkovskyi, V. (2020). Formalization of problem and justification of the set of principles of construction of the system of restoration of weapons and military equipment. Journal of Scientific Papers "Social Development and Security", 10(4), 128-138. DOI: 10.33445/sds.2020.10.4.12

7. Шишанов, М. О. Методологічні основи структурного синтезу систем відновлення озброєння та військової техніки угруповання військ / М. О. Шишанов, М.М. Шевцов, О.Л. Чеченкова // Озброєння та військова техніка. - 2017. - № 3(15). С. 6670. DOI: 10.34169/2414-0651.2017.3(15).6670

8. Дачковський В.О. Математична модель функціонування системи відновлення озброєння та військової техніки / Дачковський В.О., Стрельбіцький М.А. // "Сучасні інформаційні технології у сфері безпеки та оборони", НУОУ. - 2020. - № 2(38) C. 87 - 94. DOI: 10.33099/23117249/2020-38-2-87-94

9. Основы совершенствования системы восстановления техники и вооружения Сухопутных войск Советской Армии. - М.: Изд. академии БТВ, 1976. - 135 с.

10. Радченко Л.М. Методика оцінювання відновлюваності озброєння та військової техніки / Л.М. Радченко, В.О. Дачковський // науковий журнал "Сучасні інформаційні технології у сфері безпеки та оборони", HYOY. - 2019. - № 3(36) C. 89 - 96. DOI: 10.33099/2311-7249/2019-36-3-89-96

11. Баранов А., Баранов Ю., Іванський В., \& Малюк В. (2020). Аналіз факторів, які впливають на ефективність функціонування системи технічного обслуговування і ремонту машин інженерного озброєння. Збірник наукових праць Національної академії Державної прикордонної служби України. Серія: військові та технічні науки, 81(3), 281-290. DOI: 10.32453/3.v81i3.476

12. Ставицкий О. Н. Формализация задачи оценки возможностей восстановления утраченной боеспособности вооружения во время ведения боевых действий / О.Н. Ставицкий, Г.Н. Зубрицкий, В.В. Воинов // Наука і техніка Повітряних Сил Збройних Сил України. - 2013. - № 2(11) С. 112-115. URL:

http://nbuv.gov.ua/UJRN/Nitps_2013_2_24

13. Шишанов М. О. Обґрунтування методу моделювання процесу функціонування системи відновлення озброєння та 
військової техніки угруповання військ / М. О. Шишанов, А.В. Гуляєв, М.М. Шевцов // Озброєння та військова техніка. - 2017. №1(13). С. 75-77. DOI: 10.34169/24140651.2017.1(13).75-77

14. Dachkovsky, V., \& Kondratiuk, I. (2020). Analysis of the fleet of military vehicles that will need to be restored by rolling stock maintenance and repair. Journal of Scientific Papers "Social Development and Security", 10(6), 216-228. DOI: $10.33445 /$ sds.2020.10.6.20

15. Kotsyuruba, V. (2017). Formulation of the problem and substantiation of the set of principles of constructing an adaptive mine- clearance system under conditions of resource constraints. Journal of Scientific Papers "Social Development and Security", 2(2), 3-11. DOI: 10.5281/zenodo.1117323

16. Kondratyuk, I. (2021). Analysis of the development of mobile maintenance and repair of military vehicles. Journal of Scientific Papers "Social Development and Security", 11(1), 52-69. DOI: 10.33445/sds.2021.11.1.6

17. Dachkovskyi, V., Sampir, O., \& Horbachova, Y. (2020). Methodical approach to evaluation of economic efficiency of repairing the weapons and military equipment. VUZF Review, 5(1), 22-30. DOI: 10.38188/25349228.20.1.03

\title{
Методический подход для формулирования требований к системе восстановления вооружения и военной техники
}

\footnotetext{
Владимир Коцюруба * 1 А; Вадим Сивак 2 в; Олег Угринович ${ }^{3}$ А

Corresponding author: * ${ }^{2}$ доктор технических наук, профессор, профессор кафедры, e-mail: kotcuru@ukr.net, ORCID: 0000-0001-6565-9576 ${ }^{2}$ доктор технических наук, профессор, ведущий научный сотрудник научно-исследовательской лаборатории, e-mail: vadimsivak@gmail.com, ORCID: 0000-0002-8262-4831

${ }^{3}$ кандидат военных наук, профессор кафедры, е-mail: olegenya999@gmail.com, ORCID: 0000-0001-6644-7620

А Национальный университет обороны Украины имени Ивана Черняховского, г. Киев, Украина

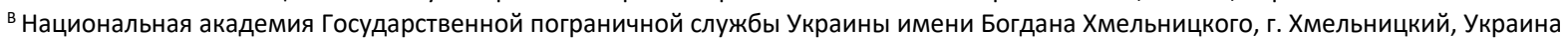

\begin{abstract}
Аннотация
При планировании общевойскового боя (операции) органами управления определяются возможности системы восстановления вооружения и военной техники, которая является составной частью общей системы обеспечения войск (сил). Именно от эффективности функционирования системы восстановления вооружения и военной техники зависит уровень укомплектованности воинских частей (подразделений) исправными образцами вооружения и военной техники, определяет уровень их боеспособности.

Опыт выполнения задач военными частями (подразделениями) на территории Донецкой и Луганской областей указывает на то, что система восстановления вооружения и военной техники не в полной мере обеспечивает выполнение задач по своевременному восстановлению поврежденных образцов вооружения и военной техники.

Основные задачи системы восстановления вооружения и военной техники в ходе боевых действий (операции), заключаются в технической разведке, эвакуации, ремонте и техническом обслуживании ВВТ. Соответственно на иерархическом уровне основные задачи для тактического звена заключаются в поддержании боевого потенциала воинских частей (подразделений) путем восстановления всего ремонтного фонда за счет проведения текущих ремонтов, а оперативном в периодическом пополнении воинских частей (подразделений) вооружением и военной техникой за счет проведения средних ремонтов.

Критерием достижения системой поставленной цели определены заданное количество исправного вооружения и военной техники в строю на конец операции, а критерием выполнения задач по уровням иерархии определена эффективность восстановления вооружения и военной техники. В статье определено, что если система восстановления тактического уровня не будет охватывать весь ремонтный фонд, то он будет передаваться
\end{abstract}


в оперативный уровень, что приведет к снижению эффективности системы восстановления оперативного звена.

Ключевые слова: эффективность, восстановление вооружения и военной техники, ремонтный фонд.

\title{
Methodical approach for formulating requirements for the restoration system of armaments and military equipment
}

\author{
Volodymyr Kotsyuruba * 1 A; Vadym Sivak ${ }^{2}$ B; Oleh Uhrynovych 3 A \\ Corresponding author: * 1 Dr of Technical Sciences, Professor, Professor of the Department, e-mail: kotcuru@ukrl.net, ORCID: 0000-0001-6565-9576 \\ ${ }^{2}$ Dr of Technical Sciences, Prof, leading researcher of the research laboratory, e-mail: vadimsivak@gmail.com ORCID: 0000-0002-8262-4831 \\ ${ }^{3}$ Candidate of Military Sciences, Professor of the Department, e-mail: olegenya999@gmail.com, ORCID: 0000-0001-6644-7620 \\ A National Defence University of Ukraine named after Ivan Cherniachovskyi, 28, Povitroflotsky, ave, Kyiv, 03049, Ukraine \\ ${ }^{B}$ National Academy of the State Border Service of Ukraine named after Bogdan Khmelnitsky, Khmelnitsky, Ukraine
}

\begin{abstract}
When planning a combined arms battle (operation), command and control bodies determine the capabilities of the system for restoring weapons and military equipment, which is an integral part of the overall system for supporting troops (forces). The level of staffing of military units (subdivisions) with serviceable models of weapons and military equipment depends on the efficiency of the functioning of the system for restoring weapons and military equipment and determines the level of their combat effectiveness.

The experience of performing tasks by military units (subdivisions) on the territory of Donetsk and Lugansk regions indicates that the system for the restoration of weapons and military equipment does not fully ensure the fulfillment of tasks for the timely restoration of damaged weapons and military equipment.

The main tasks of the system for restoring weapons and military equipment in the course of hostilities (operations) are technical reconnaissance, evacuation, repair and maintenance of weapons and military equipment. Accordingly, at the hierarchical level, the main tasks for the tactical echelon are to maintain the combat potential of military units (subunits) by restoring the entire repair fund through routine repairs, and operatively in the periodic replenishment of military units (subunits) with weapons and military equipment through medium repairs.

The criterion for the achievement of the set goal by the system is determined by the specified number of serviceable weapons and military equipment in service at the end of the operation, and the criterion for the fulfillment of tasks according to the hierarchy levels is the effectiveness of the restoration of weapons and military equipment. It is determined in the article that if the tactical level recovery system does not cover the entire repair fund, then it will be transferred to the operational level, which will lead to a decrease in the efficiency of the operational level recovery system.
\end{abstract}

Keywords: efficiency, restoration of weapons and military equipment, repair fund.

\section{References}

1. Vlasov I. O., Vorobyov O. M., Nakonechny O. V., Sereda, Yu. S. (2020). Substantiation of conceptual and scientific approaches to the development of a unified logistics system in the Armed Forces of Ukraine. Collection of scientific works "Ivan Kozhedub Kharkiv National University of the Air Force, Kharkiv. № 2 (64). Pp. 12-18. DOI: 10.30748/zhups.2020.64.02.
2. Dachkovsky V. O., Kotsyuruba V. I. (2020). Methods for evaluating the effectiveness of the functioning of the system of weapons and military equipment. Modern information technologies in the field of security and defense, № 1 (37) Pp. 5-14. DOI: 10.33099/23117249/2020-37-1-5-14.

3. Chuev Yu. V. Research of operations in military 
affairs. Moscow: Military Publishing, 1970. 256 p.

4. Syrotenko, A., Datsenko, I., Kotsiuruba, V., Yalnytskyi, O., Holda, O., Nedilko, O., Dachkovskyi, V. Experimental investigation of impact of injury measures on the protection screens of combat armoured vehicles. Strength of Materials and Theory of Structures. 2020, No. 104, p. 117-135. DOI: 10.32347/24102547.2020.104.117-135

5. Kovalenko O. A. (2016). Estimation of possibilities of repair and restoration bodies for evacuation of damaged samples of weapons and military equipment. Modern information technologies in the field of security and protection. № 2 (22). Pp. 149-154. - Available from:

http://nbuv.gov.ua/UJRN/sitsbo_2016_1_12

6. Dachkovskyi, V. (2020). Formalization of problem and justification of the set of principles of construction of the system of restoration of weapons and military equipment. Journal of Scientific Papers "Social Development and Security», 10(4), 128-138. DOI: $10.33445 /$ sds.2020.10.4.12

7. Shishanov, M. O., Shevtsov, M. M., Chechenkova, O. L. (2017). Methodological bases of structural synthesis of systems of restoration of armament and military equipment of grouping of troops. Weapons and military equipment. № 3 (15). Pp. 66-70. DOI: 10.34169/2414-0651.2017.3(15).66-70

8. Dachkovsky V. O., Strelbitsky M. A. (2020). Mathematical model of functioning of the system of armament recovery and military equipment. Modern information technologies in the field of security and defense, № 2 (38) P. 87-94. DOI: 10.33099/2311-7249/2020-38-287-94

9. Fundamentals of improving the system of restoration of equipment and weapons of the Land Forces of the Soviet Army. Moscow: Ed. Academy of BTV, 1976. $135 \mathrm{p}$.

10. Radchenko L. M., Dachkovsky V.O. (2019). Methods for assessing the recoverability of weapons and military equipment. Modern information technologies in the field of security and defense, № 3 (36) Pp. 89-96.
11. Baranov A., Baranov Y., Ivanskyy V., \& Malyuk V. (2020). Analysis of factors influencing the efficiency of the system of maintenance and repair of engineering weapons. Collection of Scientific Works of the National Academy of the State Border Guard Service of Ukraine. Series: Military and Technical Sciences, 81(3), 281-290. DOI: 10.32453/3.v81i3.476

12. Stavitsky O.N., Zubrytckyi G.N., Voinov B.B. (2013). Formalization of the task of assessing the possibility of restoring the lost combat capability of weapons during combat operations. Science and Technology of the Air Force of the Armed Forces of Ukraine. № 2 (11) Pp. 112-115. - Available from: http://nbuv.gov.ua/UJRN/Nitps_2013_2_24

13. Shishanov M. O., Gulyaev, A. V., Shevtsov M. M. (2017). Substantiation of the method of modeling the process of functioning of the system of restoration of armaments and military equipment of troops. Weapons and military equipment. №1 (13). Pp. 75-77. DOI: 10.34169/2414-0651.2017.1(13).75-77

14. Dachkovsky, V., \& Kondratiuk, I. (2020). Analysis of the fleet of military vehicles that will need to be restored by rolling stock maintenance and repair. Journal of Scientific Papers "Social Development and Security", 10(6), 216-228. DOI: 10.33445/sds.2020.10.6.20

15. Kotsyuruba, V. (2017). Formulation of the problem and substantiation of the set of principles of constructing an adaptive mineclearance system under conditions of resource constraints. Journal of Scientific Papers «Social Development and Security», 2(2), 3-11. DOI: 10.5281/zenodo.1117323

16. Kondratyuk, I. (2021). Analysis of the development of mobile maintenance and repair of military vehicles. Journal of Scientific Papers "Social Development and Security", 11(1), 52-69. DOI: 10.33445/sds.2021.11.1.6

17. Dachkovskyi, V., Sampir, O., \& Horbachova, Y. (2020). Methodical approach to evaluation of economic efficiency of repairing the weapons and military equipment. VUZF Review, 5(1), 2230. DOI: $10.38188 / 2534-9228.20 .1 .03$ 